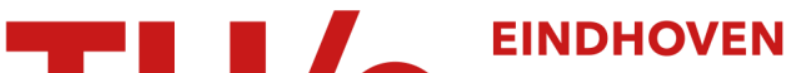

\section{Formation of the 7-triphenylphosphonio-norbornen-7-ylium dication : a non-classical dication}

\section{Citation for published version (APA):}

Schipper, P., Castenmiller, W. A. M., Haan, de, J. W., \& Buck, H. M. (1973). Formation of the 7triphenylphosphonio-norbornen-7-ylium dication : a non-classical dication. Journal of the Chemical Society, Chemical Communications, (16), 574-575. https://doi.org/10.1039/c39730000574

DOI:

10.1039/c39730000574

Document status and date:

Published: 01/01/1973

\section{Document Version:}

Publisher's PDF, also known as Version of Record (includes final page, issue and volume numbers)

\section{Please check the document version of this publication:}

- A submitted manuscript is the version of the article upon submission and before peer-review. There can be important differences between the submitted version and the official published version of record. People interested in the research are advised to contact the author for the final version of the publication, or visit the $\mathrm{DOI}$ to the publisher's website.

- The final author version and the galley proof are versions of the publication after peer review.

- The final published version features the final layout of the paper including the volume, issue and page numbers.

Link to publication

\section{General rights}

Copyright and moral rights for the publications made accessible in the public portal are retained by the authors and/or other copyright owners and it is a condition of accessing publications that users recognise and abide by the legal requirements associated with these rights.

- Users may download and print one copy of any publication from the public portal for the purpose of private study or research.

- You may not further distribute the material or use it for any profit-making activity or commercial gain

- You may freely distribute the URL identifying the publication in the public portal.

If the publication is distributed under the terms of Article 25fa of the Dutch Copyright Act, indicated by the "Taverne" license above, please follow below link for the End User Agreement:

www.tue.nl/taverne

Take down policy

If you believe that this document breaches copyright please contact us at:

openaccess@tue.nl

providing details and we will investigate your claim. 


\title{
Formation of the 7-Triphenylphosphonio-norbornen-7-ylium Dication: a Non-classical Dication
}

\author{
By Pieter Schipper,* Wim A. M. Castenmiller, Jan W. de HaAn, and Henk M. Buck \\ (Department of Organic Chemistry, Eindhoven University of Technology, The Netherlands)
}

\begin{abstract}
Summary While the norbornen-7-ylium cation dissolved dipositive ion were formed. ${ }^{1}$ We discuss here the preparain liquid $\mathrm{SO}_{2}$ does not undergo 7-substitution with $\mathrm{PPh}_{3}$, tion of compounds (III) and (IV) and the dipositive ion (V) the analogous reaction with the 7-methoxynorbornen- (see Scheme).

7-ylium cation produces the 7-methoxynorbornen-7-yl- Attempts to prepare the norbornadien-7-ylphosphonium triphenylphosphonium cation; the intermediate 7-tri- salt by treatment of norbornadien-7-yl chloride or the phenylphosphonio-norbornen-7-ylium dication could be norbornadien-7-ylium cation with $\mathrm{PPh}_{3}$ in liquid $\mathrm{SO}_{2}$ failed. detected.

Only weakly nucleophilic phosphines like $\mathrm{P}\left(\mathrm{C}_{6} \mathrm{~F}_{5}\right)_{3}$ appeared to form 7-substituted salts. Probably, charge delocalisation IN order to investigate the 7-cations and 7-radicals of in the norbornadien-7-ylium gives rise to 2- or 3-subunsaturated norbornyl systems, we tried to prepare the stituted products with stronger nucleophiles, like $\mathrm{PPh}_{3}$, and 7-triphenylphosphonium salts, which could serve as pre- the latter products apparently decompose under the recursors of these intermediates. A similar method was action conditions. ${ }^{2}$ These nucleophiles underwent similar successful in the oxidation of diphenylmethyltriphenyl- reactions with the norbornen-7-ylium cation, but reaction phosphonium methylide when the related radical and of 7-anti-chloronorbornene with $\mathrm{PPh}_{3}$ in formic acid, where
\end{abstract}


equilibrium conditions are prevailing, does yield the 7substituted product.

Stabilisation of charge by double-bond participation in norbornen-7-ylium cations decreases with increasing electron donating ability of the 7-substituents. ${ }^{3}$ Reaction of $\mathrm{PPh}_{3}$ with 7-chloro-7-methoxynorbornene gives rise only to substitution of $\mathrm{PPh}_{3}$ at the 7-position.

Reaction of 7,7-dimethoxynorbornene with $\mathrm{PCl}_{5}$ yields a mixture of the isomers (I) $(76 \%)$ and (II) $(24 \%)$, which reacts readily with $\mathrm{PPh}_{3}$ in liquid $\mathrm{SO}_{2}\left(-60^{\circ}\right)$ to yield a mixture $(28: 72)$ of the isomeric cations (III) and (IV). At $-60^{\circ}$, the ratio of the isomers is constant, but at ca. $-14^{\circ}$, compound (IV) isomerises to (III), which is obtained in crystalline form at room temperature. Both isomers (III) and (IV) produce the dication (V) in liquid $\mathrm{SO}_{2}$ with $\mathrm{HSO}_{3} \mathrm{~F}-\mathrm{SbF}_{5}$ at $-60^{\circ}$. Quenching of this dication with methanol yields only (III). The structures of compounds (I)-(V) were confirmed by their n.m.r. $\left({ }^{1} \mathrm{H}\right.$ and ${ }^{\left.{ }^{13} \mathrm{C}\right)}$ spectra.

In solution in liquid $\mathrm{SO}_{2}$, isomers (I) and (II) undergo an exchange reaction at higher temperatures. This interconversion and the formation of a mixture of products in the reaction with $\mathrm{PPh}_{3}$ indicate absence of double-bond participation in the intermediate 7-methoxy-norbornen-7-yljum cation.

First-order kinetics were observed for the isomerisation of compound (IV) to (III) in liquid $\mathrm{SO}_{2}$ at $-14^{\circ}(k=2.7 \times$ $10^{-4} \mathrm{~S}^{-1}$ ). In liquid $\mathrm{SO}_{2}-\mathrm{HSO}_{3} \mathrm{~F}$, compound (III) is stable, whereas compound (IV) decomposes at a rate comparable to the rate of isomerisation in liquid $\mathrm{SO}_{2}$. During the decomposition no 7-methoxy-carbonium ion was observed, although this cation was shown to be stable under these conditions by adding (I) and (II). Thus, isomerisation of (IV) to (III) proceeds via the dication (V), which is not stable in liquid $\mathrm{SO}_{2}-\mathrm{HSO}_{3} \mathrm{~F}$. In this dication, double-

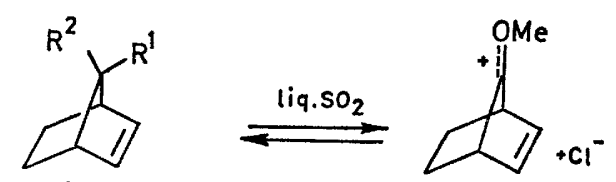

(I) $\mathrm{R}^{1}=\mathrm{Cl}, \mathrm{R}^{2}=\mathrm{OMe}$

(II) $\mathrm{R}^{1}=\mathrm{OMe}, \mathrm{R}^{2}=\mathrm{Cl}$

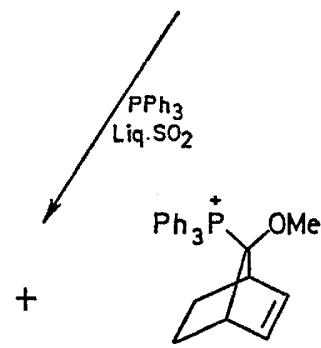

(IV)
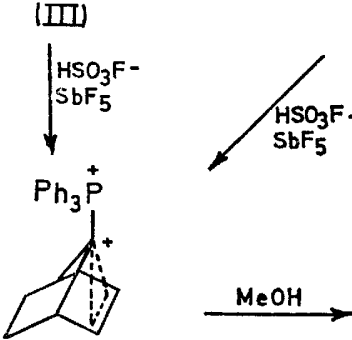

(Y)

bond participation, which is increased by the $\mathrm{PPh}_{3}{ }^{+}$group explains the irreversible formation of compound (III) (vide supra).

1 P. Schipper and H. M. Buck, Phosphorus, 1971, 1, 93.

2 P. Schipper and H. M. Buck, Phosphorus, to be published.

${ }^{3}$ P. G. Gassman and A. F. Fentiman, jun., J. Amer. Chem. Soc., 1969, 91, 1545; 1970, 92, 2549; H. G. Richey, jun., J. D. Nichols, P. G. Gassman, A. F. Fentiman, jun., S. Winstein, M. Brookhart, and R. K. Lustgarten, ibid., p. 3783; R. K. Lustgarten, M. Brookhart, and S. Winstein, Tetrahedron Letters, 1971, 2, 141. 